\title{
Ensuring the integrity of clinical practice guidelines: a tool for protecting patients
}

The authors of this Feature (BMJ 2013;347:f5535, doi:10.1136/ bmj.f5535) would like to declare the following competing interest, which should have been declared at the time of publication: Jerome R Hoffman has consulted on lawsuits involving allegations of negligence related to non-use of thrombolysis in stroke. He donates all fees from such consulting to charity, and takes no personal reimbursement for this work.

Cite this as: BMJ 2014;348:g1335

๑ BMJ Publishing Group Ltd 2014 